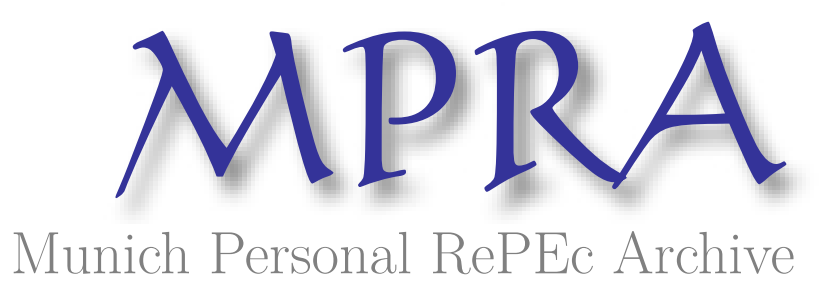

\title{
Considerations about the Influence Factors on the Competitiveness of SME's from Western Region of Romania
}

Bibu, Nicolae Aurelian and Sala, Diana and Pantea, Marius and Bizoi, Gabriel

West University of Timisoara

30 May 2008

Online at https://mpra.ub.uni-muenchen.de/9479/

MPRA Paper No. 9479, posted 08 Jul 2008 00:52 UTC 


\title{
CONSIDERATIONS ABOUT THE INFLUENCE FACTORS ON THE COMPETITIVENESS OF SME'S FROM WESTERN REGION OF ROMANIA
}

\author{
Prof. Dr. Nicolae Bibu, \\ Universitatea de Vest, Facultatea de Economie şi Administrarea Afacerilor, Timisoara \\ Str. J.H.Pestalozzi nr. 16, 300115, Timisoara, Tel: +40-256-592506 +40-256-592526 \\ Romania \\ Email addresses: nicolae.bibu@,fse.uvt.ro \\ Conf. dr. Diana Sala \\ Universitatea de Vest, Facultatea de Economie şi Administrarea Afacerilor, Timisoara \\ Str. J.H.Pestalozzi nr. 16, 300115, Timisoara, Tel: +40-256-592506 +40-256-592526 \\ Romania \\ Email addresses: diana.sala@,fse.uvt.ro \\ Conf. dr. Marius Pantea \\ Universitatea de Vest, Facultatea de Economie şi Administrarea Afacerilor, Timisoara \\ Str. J.H.Pestalozzi nr. 16, 300115, Timisoara, Tel: +40-256-592506 +40-256-592526 \\ Romania \\ Email addresses: marius.pantea@,fse.uvt.ro \\ Lector drd. Gabriel Bizoi \\ Universitatea de Vest, Facultatea de Economie şi Administrarea Afacerilor, Timisoara \\ Str. J.H.Pestalozzi nr. 16, 300115, Timisoara, Tel: +40-256-592506 +40-256-592526 \\ Romania \\ Email addresses: gabibizoi@yahoo.com
}

\begin{abstract}
There are many ways in which the firm competitiveness can be understood in the related literature. The purpose of this research is to undertake a better understanding of expectations and concerns of small and medium sized enterprises from Romanian Western region, in term of competitiveness. This study presents preliminary results of a finished grant focused on SME's competitiveness. There are some positive and negative factors in our research which are influencing firms' competitiveness. This study has confirmed our hypothesis. The external environment influence on the competitiveness of SME's is strong and contributes decisively to their performance.
\end{abstract}

KEY WORDS: SME's, competitiveness, growth, external factors, Romania

\section{LITERATURE REWIEV}

In the related literature there are many ways in which the firm competitiveness can be understood. There is not a universally accepted definition of competitiveness and there is a lack of precise definition of this concept. The terminology comes from business literature. We discuss here about firm competitiveness.

Firm competitiveness is the basic capability of perceiving changes in both external and internal environment and the capability of adapting to these changes in a way that the profit flow 
generated guarantees the long term operation of the firm. There is an ongoing struggle for survival. (Chikan, 2001).

Tyson (1993) argued that competitiveness is the ability to produce goods and services that meet the test of international competition, while the citizens enjoy a standard of living that is both rising and sustainable.

Competitiveness should be understood as the ability of companies, industries, regions, nations to generate, while being and remaining exposed to international competition, relatively high factor income and employment on a sustainable basis. (OECD 1998)

The opinion of Krugman (1994) is that competitiveness is nothing but a different way of saying productivity, taking into account the rate of growth of one firm relative to others.

The concept of competitiveness reminds of competitive advantage, an important subject in strategic management studies. A firms performance is affected by its competitive advantage.

Firm level competitiveness indicates its ability to design, produce and market products superior to those offered by competitors. Competitiveness is considered synonyms with success (achievement of company objectives).

The enterprise's level of competitiveness, according to S.A Khader, would mean that yhe enterprise should be able to achieve the following: ability to retain the customer base as well add on to it and to enhance its market share; acknowledged demonstration of growth; ensuring continuous improvement in productivity, quality service, product development.

G. Johnson şi K. Scholes (1993) shows the importance of external environment in formulating competitive strategy in an uncertain environment. The competitive position of an enterprise in the industry in which competes depends on many factors: market share, the quality of used resources, answers flexibility to market pressure, financial performance. On the other hand, A. Thompson şi A. J. Strickland (1998) argue that firms have great chances to became profitable and gain success in their industry if they obtain and keep durable competitive advantage.

Competitiveness is determined by productivity, and depends on firms strategies, it is partially, the results of relationship between firms and local business environment, depends on social and economic objectives synergy and is influenced by factors from external environment. (M. Porter).

The firm level of competitiveness can be measured by the capacity to invest, ability to generate and introduce new products in current markets and the ability to compete in foreign markets (ANIMMC, 2006)

A competitive firm knows how to use its strengths to exploit environmental opportunities and to reduce the negative influences of some external environment factors.(Dănăiaţă, Bibu, Predişcan, 2006)

In related literature we have identified find some indicators of competitiveness performance, such as the following:

- market share

- growth in sales (our firms succeed in this)

- growth in exports (not for our firms) 
- new product introduction

- good image and reputation

As we know, firm competitiveness is basically a function of two factors: their customers, and

1. the extent a company can identify those value dimensions that are important for

2. the sum of resources and capability that makes a firm able to create and deliver the identified important value dimensions for the customer (Gelei, 2004).

Starting a new business requires more than just an idea. It requires a person, an entrepreneur who has used his judgment and professional and managerial skills with his risk taking to ensure the success of his own business. Before presenting our findings, we must ask a simple question: who are entrepreneurs? Are they special people? We fully agree with the following definition „Entrepreneurs are those individuals who discover markets needs and launch new firms to meet those needs" (Longenecker, Moore, Petty, Palich, 2006)

\section{RESEACH METHODOLOGY}

This study presents the final results of a CNCSIS grant, for the period of 2006-2007, focused on SME's competitiveness. The research method included mail survey, telephone, personal interviews of small business owners. Contact lists was received from official firms database, based on previous research of our research team colleagues. The sample included only firms with income statement, balance sheet (1000 firms from Timis county).

We have received and processed through SPSS program, 134 questionnaires with 125 valid responses. We did an explorative research.

The research team has identified 7 topics:

- firms and the their evolution during the last 5 years;

- the entrepreneur profile;

- the firms profile (resources);

- the characteristics of the change management process;

- the external environment analysis;

- the EU integration effects on competitiveness;

- the entrepreneur and ethic.

The firms questioned are from different fields: production $(30,1 \%)$, trade $(39,3 \%)$, financial and other services $(8,3 \%)$, construction $(8,35 \%)$, communications and transports $(3 \%)$, others $(19.5 \%)$. The majority of questioned enterprises are in front of first $50 \%$ of competitors.

We have designed a questionnaire, with 4 pages, 6 sections and 26 questions. The first section contains information about founder, firm and field. The following sections contain information about:

1. turnover evolution in the last 5 year;

2. strengths and obstacles;

3. the changing management process characteristics;

4. the analysis and prognoses of external environment;

5. the effect of EU integration on SME's competitiveness.

Our research was based on the following assumptions: the SME's evolution, and SME's growth is both a development and a change process, influenced by external environment and by the entrepreneur profile and competency. The SME's competitiveness in the researched firms is dependent on external and internal environment of that company.

The firms were divided into 4 categories, for statistical reasons: 1. very low dynamic firms, 2: low dynamic firms, 3. high dynamic and 4. very high dynamic firms. We are presenting 
here only the results concerning the influences of entrepreneurs and external environment on SME's, and some strengths and obstacles for their business.

\section{DISCUSSION OF RESULTS}

a) about entrepreneurs

Data processing began with company, entrepreneur and its activity. About the entrepreneur position in company, 7,5\% are owners, 53\% are also managers and 39,6\% have an other position than manager. It is important that $92,5 \%$ entrepreneurs are also managers in their company, in most than $50 \%$ cases they are top managers.

Only $28,4 \%$ of respondents are women and $71,6 \%$ are men. This is an interesting situation in Romanian business environment, and, of course, in our region, in the last years, more women became entrepreneurs. We do not have relevant research study about this phenomenon in our region but we believe that there are some environmental factors including socio-cultural and economics factors (Timis county is a well developed county, also local culture more open to western influence, urban location of companies) which are influencing women decisions to became entrepreneur.

We are sure that there are some similarities and differences between the types of entrepreneurial features associated with different types of organizations. One conclusion is that new firms were founded by entrepreneurs who are young and middle-aged.

In our study, entrepreneurs according to age, we found the following:

- the average age for entrepreneur is 42,4 years.

- the younger age was 21 year and the oldest was 66 years.

- from 21 years to $35: 29,6 \%, 35$ to 55 years: $62,8 \%$; more than 55 years: $7,6 \%$

We don't have information concerning identification of entrepreneurial typologies.

Questions were asked about the education, training and business experience. The owners/managers have higher education $(58,8 \%)$ and $33,6 \%$ have followed managerial training programs. Some entrepreneurs $(30 \%)$ have some experience in the field, before starting a business. They worked in different state or private enterprises, prior to starting their first business.

The managers in our research have identified some success factors for their business. One of them is related with managerial competence. They believe that the management team has good managerial competency $(64,1 \%)$; while only $9,6 \%$ entrepreneurs have acceptable managerial competences.

\section{b) business evolution}

Also, we have found the following results:

- turnover was growing slowly during the last 5 years $(2002 / 2006)$;

- the profitability rate was $18 \%$ (average for the whole sample) with some differences: IT, $(40 \%)$, industry-service (18-20\%), constructions $(12,5 \%)$, trade $(16 \%)$;

- the products are sold especially in the domestic market, Romanian one;

- the majority of the questioned enterprises are in front of first $50 \%$ of their competitors;

- the owners/managers have higher education (58,8\%) and 33,6\% have followed managerial training programs;

- the managerial teams are perceived with having adequate competence $(64 \%)$.

The net profit growth was continuous, and the average rate of growth was $9.55 \%$ / year. Only one enterprise have reported a very high level of growth in IT. The main factors identified for sustaining continuous growth were:

-improvement of managerial skills

-distribution channels 
-cost reducing

-modernization in technology,

-growth in production capacity

-improvement in people motivation.

Work productivity, which reflects the efficiency in human resources used has increased in the last 5 year through modernization in technology, improvement in people motivation and improvement of managerial skills.

\section{c) business obstacles and strengths}

Our research reveals some success factors for small and medium enterprises. Some researchers argued that the overall competitiveness of an enterprise comes about by the performance in the following areas: economic productivity, quality, customer focus and social productivity

Firms economic strengths and successes are primarily determined by their internal management, the characteristics of the national and local business environment.

The managers of our research have identified some success factors for their business:

1. the quality of their products/services

2. the relationship with customers

3. the professional experience

4. managerial competencies

5. marketing politics

6. business financing. education.

One of the important strengths identified is the owners/managers having higher

1. the payment for delivering products is difficult

2. the workers qualification is not always at he required level

3. the weak financial power

4. the hard access to financing.

The fact that $2 / 3$ from their entrepreneurs do not have a special degree in management field is a weakness for firms. A significant number of entrepreneurs may have had previous entrepreneurial experience.

\section{d) external environment influences}

The external environment, which is complex, unstable, is influencing the small and medium sized competitiveness, and of course, management decisions.

Entrepreneurs-managers have identified some external factors with positive influences: growth of demand for their products in local markets; growth of demand for their products in foreign markets; infrastructure modernization; opportunities for financing their investments; simplified access to loans; attractive interest rates for borrowing; better quality of raw materials; modern production methods and technologies; growth in the buying power of the population; positive modifications in rules, and governmental policies.

$45,5 \%$ from questioned firms recognized that growth demand for their products in local markets is a very strong positive factor for their business, especially for firms with low performance. For most performing firms, this factor is not so important. For $84 \%$ of SME's the 
opportunity for financing their investments is also very important for business development and for profit growth average rate. For 78\% of SME's simplified access to loans is not so important for their profit growth average rate. Infrastructure modernization is not important for $72,7 \%$ of respondents on profit growth average rate.

The governmental and states institutions have an important role in firms activities. Managers considered that government and non government organizations can be more involved in consulting activities, training, creating a favorable environment for small and medium business. The most important communication channel between firms and government are county organizations for SME's, chambers for industry and trade.

Respondents considered that government can influence the market mechanisms and make them to function efficiently, and can create a favorable environment, that enables entrepreneurs to seek profits.

\section{Conclusions}

The external environment influence on SME's competitiveness is very strong. The world is changing, the environment is more uncertain, the competition is strong, the environment protection regulations are more restrictive. All these require rapid, efficient and effective answers.

Firm competitiveness must be shown like a part of territorial, local competitiveness. Economic development is a cooperation process between government, local administration, firms, research institutes and education.

The findings of this paper contribute to the study of local private small and medium size enterprise development and competitiveness.

\section{References}

1. Bygrave W, Zacharakis A, (2008) Entrepreneurship, Wiley, USA

2. Chikan A., Czako E., (2005), Kutatasi tervanullmany, versenyben a viggal, 2004,2006, gazdasagi versenykepessegunk vallati nezopontbol cimu kutatas, 1 sz, muhelytanulmany, budapesti Corvinus Egytem, workshop study no 1), Centre for research on competitiveness, Institute for Corporate Economics Corvinus University; Budapest.

3. Chikan A, (2006). National and firm competitivenes: some general considerations an $d$ the case of Hungary, proceedings, COMP REV \&:\&,

4. Danaiata I. Bibu N, Prediscan Mariana, (2006) Management, Baze Teoretice, Editura Mirton,

5. G, Johnson, K, Scholes, (1993), Exploring corporate strategy, Prentice-Hall International, Hertfordshire

6. Hornaday J. A, (1982) Research about living entrepreneurs, in Enciclopedia of entrepreneurship, Kent/Sexton/Vesper eds,

7. Khader S, A, (2001), A model for competitiveness assessment, Working paper, New Delhi

8. Krugman P, (1994), Competitiveness: A dangerous obsession, article, Foreign affaires,

8. Longenecker, J, G, Moore, C, W., Petty J. W., Palich, Leslie E., (2006) Small business management, An entrepreneurial emphasis, 13 th edition, Thompson, South-Western,

9. Porter, M, C, Ketels, (2003), UK competitiveness: moving to the next stage, DTI, Economic Papers, ESRC

10. Thompson A, Strikland A, J, (1998), Strategic Management, Irwin McGraw Hill

11. OECD, (2005), Economic Outlook, Annual competitiveness reports. 